\title{
Yolk Sac Tumor of the Temporal Lobe: Case Report
}

\section{Tumor do saco vitelino do lobo temporal: relato de caso}

\author{
Ana de Almeida Matos Monteiro Machado ${ }^{1}$ Ricardo Jorge Ferreira Taipa ${ }^{2}$ \\ Manuel Jorge Rocha Melo Pires ${ }^{2}$ Carla Maria Esteves Silva ${ }^{1}$ Mário Augusto Cunha Gomes ${ }^{1}$ \\ ${ }^{1}$ Neurosurgery Service, Hospital Santo Antonio - CHP, Porto, Portugal
${ }^{2}$ Neuropathology Department, Hospital Santo Antonio - CHP, Porto,
Portugal \\ Address for correspondence Ana Matos Machado, MD, Serviço \\ Neurocirurgia, Hospital Santo Antonio - CHP, Porto, Portugal \\ (e-mail: ana_ammm@hotmail.com).
}

Arq Bras Neurocir 2018;37:247-251.

\begin{abstract}
Germ cell tumors of the central nervous system (CNS) are usually located along the midline. Yolk sac tumor is a rare germ cell tumor very uncommonly located outside the midline, and, in such cases, it can be mistaken with other primary tumors. We report a case of a 32-year-old male patient who presented with a right temporal lobe tumor suggestive of a high grade glioma. He was submitted to a right temporal lobectomy

Keywords

- germ cell

- tumor

- yolk sac tumor

- temporal lobe

\section{Resumo}

\section{Palavras-chave}

- células germinativas

- tumor

- saco vitelino

- lobo temporal with complete tumor removal. The histological exam revealed a germ cell tumor (later confirmed to be a yolk sac tumor). The search for a primary tumor outside of the CNS (including a positron emission tomography scan) was negative, making this a primary temporal lobe yolk sac tumor. The patient was submitted to chemotherapy and radiotherapy, but died 7 months after the surgery.

Tumores de células germinativas do sistema nervoso central (SNC) geralmente se localizam ao longo da linha média. O tumor do saco vitelino é um raro tumor de células germinativas muito incomumente localizado fora da linha média, e, nestes casos, pode ser confundido com outros tumores primários. Relatamos o caso de um homem de 32 anos de idade que apresentou um tumor no lobo temporal direito com suspeita de ser um glioma de alto grau. O paciente foi submetido a uma lobotomia temporal direita com remoção completa do tumor. A histologia revelou um tumor de células germinativas (posteriormente confirmado como tumor do saco vitelino). A busca por tumor primário fora do SNC (incluindo uma tomografia por emissão de pósitrons) foi negativa, confirmando um tumor primário do saco vitelino do lobo temporal. O paciente foi submetido a quimioterapia e radioterapia, mas faleceu 7 meses após a cirurgia.
\end{abstract}

\section{Introduction}

Central nervous system (CNS) germ cell tumors account for 2 to $3 \%$ of the primary intracranial tumors, and are usually located in the midline (in the pineal or sellar regions). ${ }^{1}$ The yolk sac tumor is a relatively rare germ cell tumor. ${ }^{2,3}$ The occurrence of this type of tumor outside the midline is an exception, with very few cases described in the litera-

received

May 29, 2015

accepted

August 31, 2015

published online

October 5, 2015 10.1055/s-0035-1564829. ISSN 0103-5355. ture. ${ }^{1,2,4-6}$ When they occur in atypical locations, they are usually lesions with a cystic component and poor prognosis. ${ }^{5}$

\section{Case Report}

A 32-year-old male patient, who sought the emergency department with a headache with 2 weeks of evolution and papillary stasis. No other focal neurological signs were observed.

Copyright $\odot 2018$ by Thieme Revinter Publicações Ltda, Rio de Janeiro, Brazil

License terms

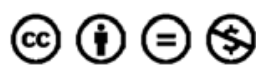


The imaging investigation revealed a right temporal intraaxial lesion with heterogeneous contrast uptake and a cystic/ necrotic area (-Fig. 1). The hypothesis of the diagnosis was high-grade glioma (HGG).

The patient underwent a right frontotemporal craniotomy with a temporal lobectomy encompassing the lesion in its entirety (-Fig. 2). The lesion had a hard, vascularized consistency, and a cystic area of yellowish content, macroscopically similar to an HGG.

Clinically, the patient improved postoperatively, without headaches or focal deficits.

The neuropathological examination revealed a germ cell tumor forming, in some places, tubular structures composed of cells with prominent nuclei, and numerous mitoses were observed. The immunocytochemical examination was positive for both $\alpha$-fetoprotein and glypican 3,(-Fig. 3), and negative for glial fibrillary acidic protein (GFAP), human chorionic gonadotropin (HCG), and epithelial markers. In this sense, a systemic investigation including a positron emission tomography (PET) scan was performed to investigate a possible primary tumor (assuming that, from the

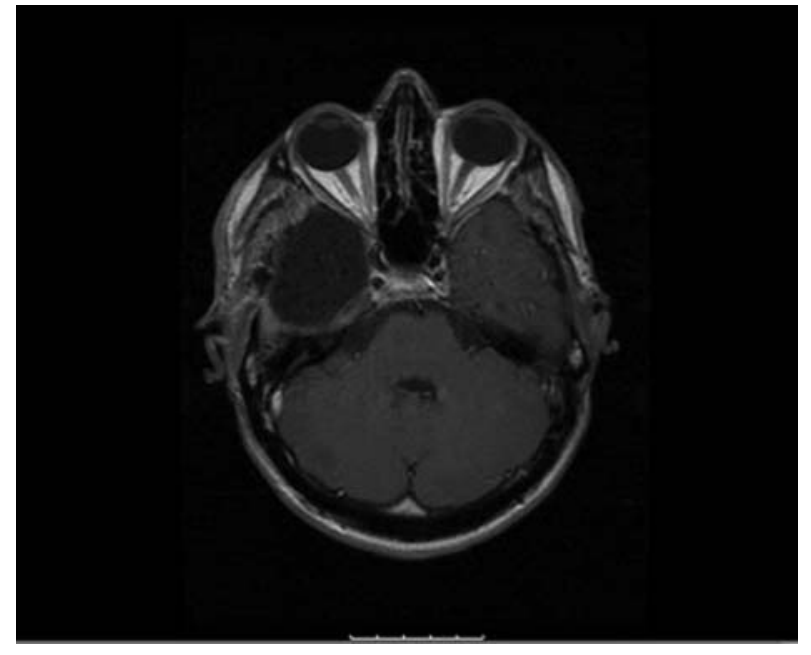

Fig. 2 Postoperative magnetic resonance imaging (axial, T1, with gadolinium) revealing right temporal lobectomy with absence of anomalous contrast uptake.
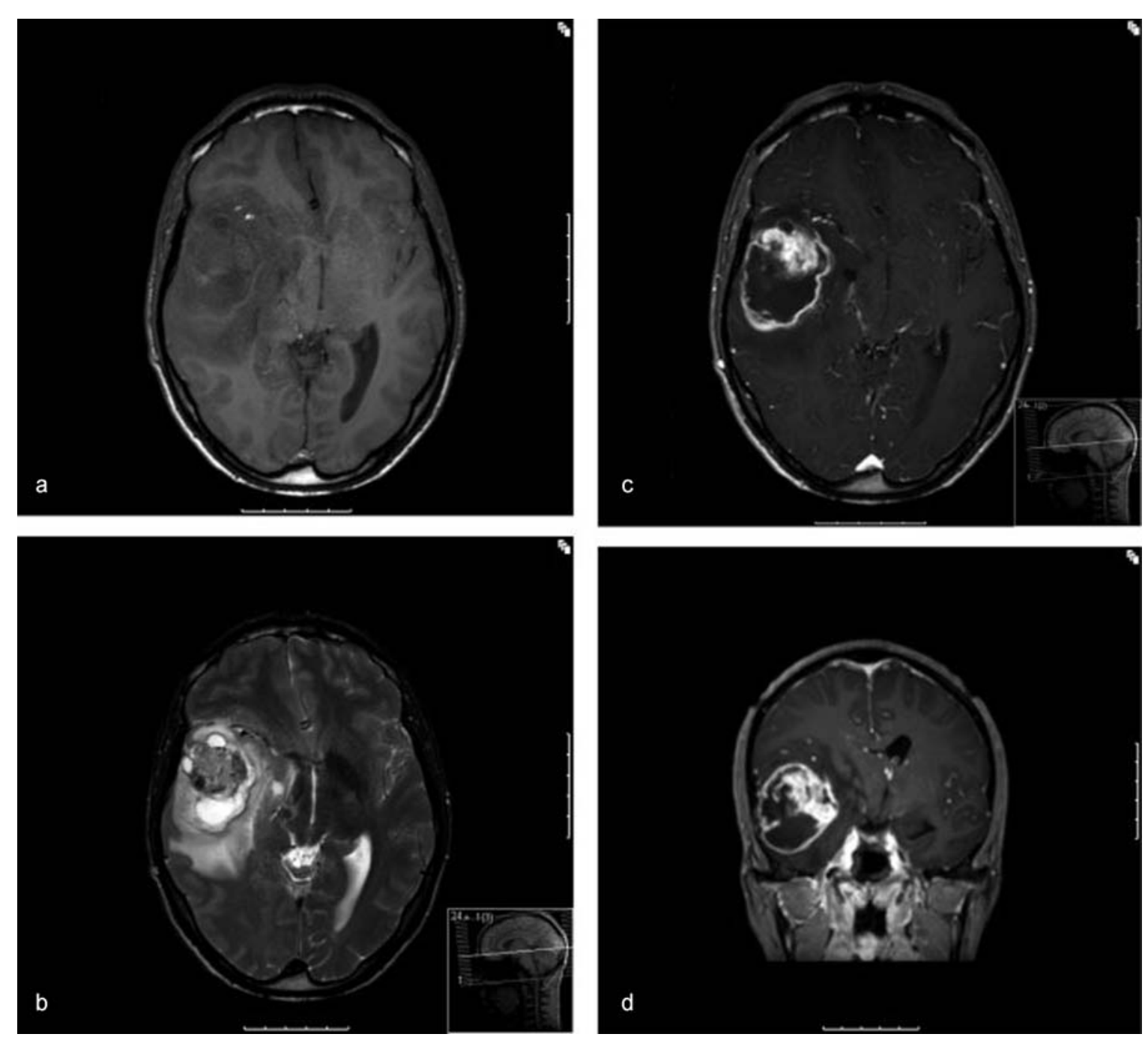

Fig. 1 Preoperative magnetic resonance imaging revealing right temporal lesion, hypointense in T1 (a), with heterogeneous signal in T2 (b), heterogeneous contrast uptake and cystic/necrotic area $(c, d)$, with mass effect on the structures of the midline. 
a
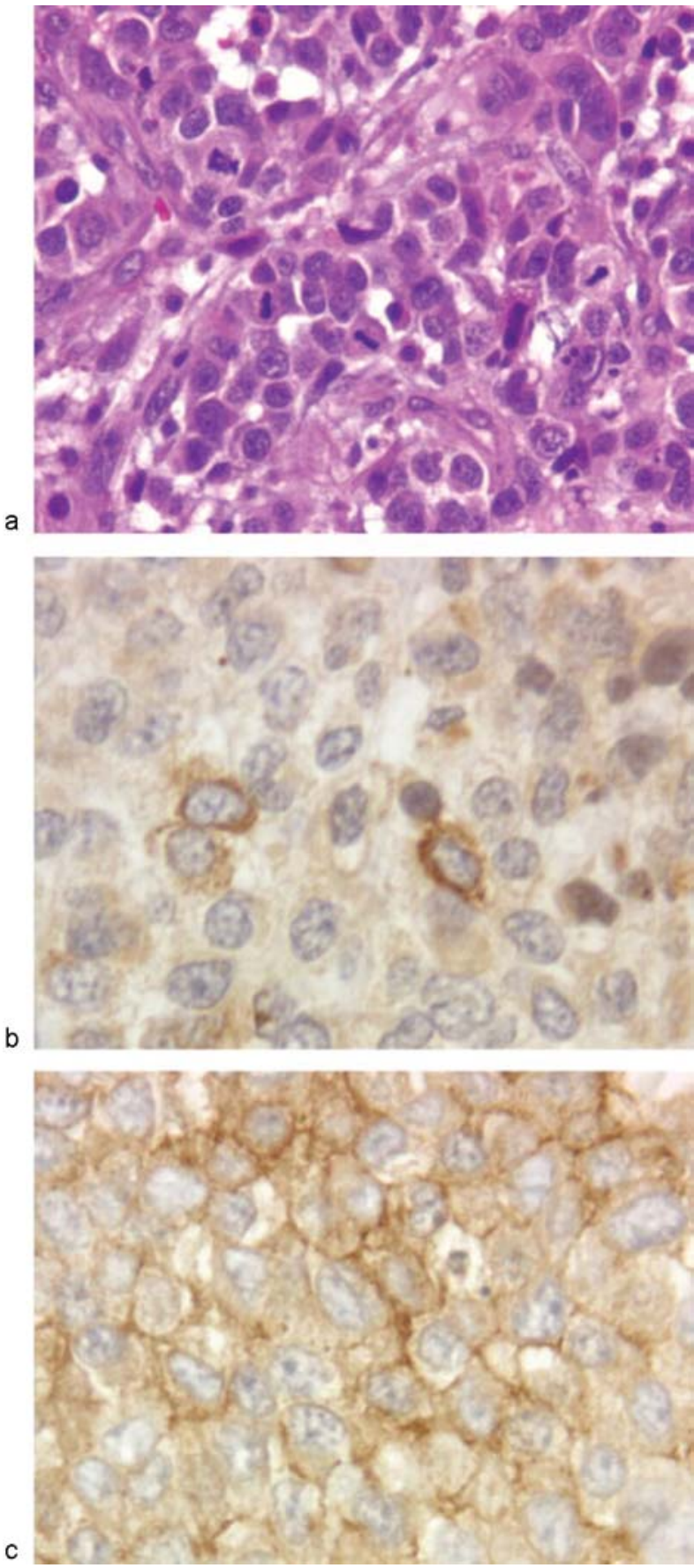

Fig. 3 Hematoxylin eosin (HE) histology (a) demonstrating neoplasia formed by lobules of nucleolated round nuclei, with numerous mitoses (arrows), positive immunocytochemistry for alpha-fetoprotein (b) and glypican 3 (c).

location of the brain lesion, it would be metastatic). The investigation was negative, and no other tumor was found. The study of the neuraxis also revealed no other lesions.

The patient was directed to four cycles of chemotherapy ifosfamide + cisplatin + etoposide (ICE), which would be followed by holocranial brain radiotherapy.

At 3 months, during the third cycle of chemotherapy, a magnetic resonance imaging (MRI) exam revealed intracranial meningeal metastases. At this time, the patient remained clinically stable. A decision was made to continue with the

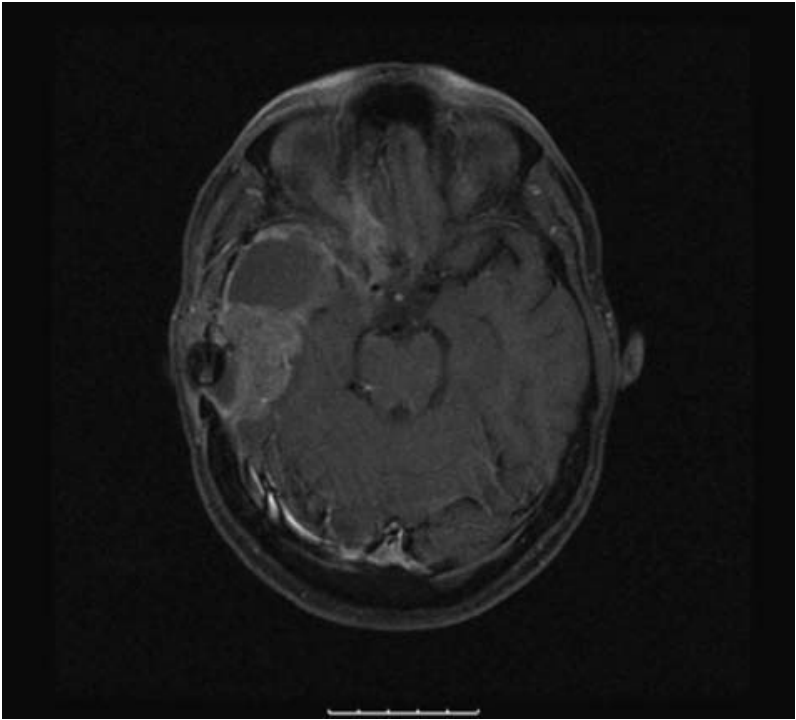

Fig. 4 Magnetic resonance imaging (axial, T1, with contrast) at 5 months with evidence of metastasis.

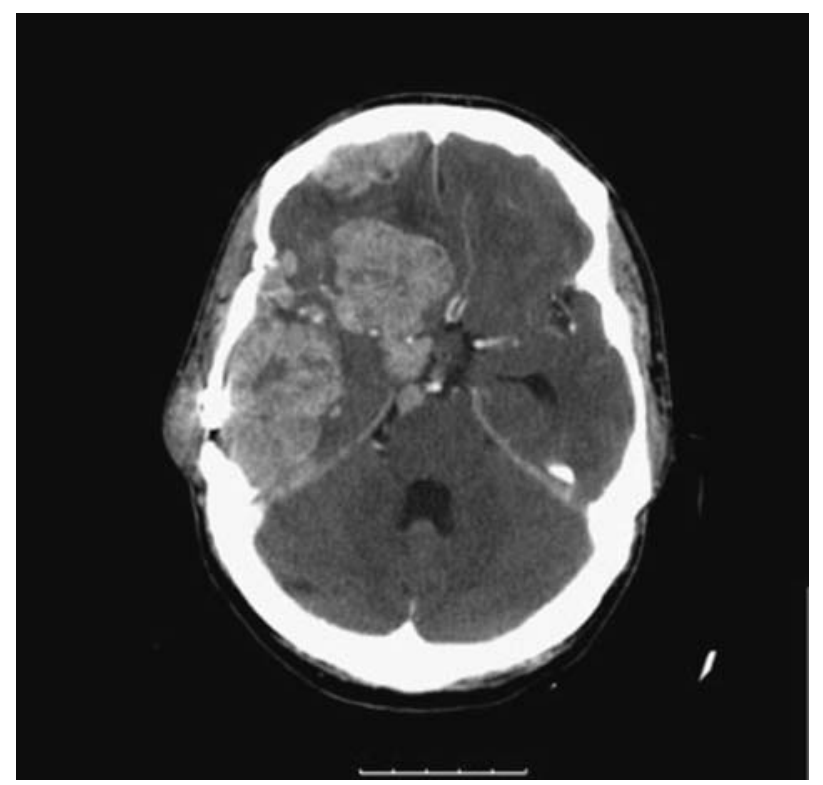

Fig. 5 Computed axial tomography (3 weeks after magnetic resonance imaging [ - Fig. 3] under radiotherapy) revealing marked lesion growth and de novo lesions.

fourth cycle of chemotherapy and subsequent radiotherapy. At an MRI exam performed at 5 months, the patient maintained the metastases already known ( - Fig. 4). Three weeks after this examination, already under radiotherapy, there was an important neurological deterioration, revealing a marked growth of metastases in the computerized axial tomography (CAT) scan, as well as new lesions (-Fig. 5). Due to the lack of response to the treatment, the radiotherapy was discontinued. The patient deteriorated rapidly to a comatose state, dying 3 weeks later, $\sim 7$ months after surgery. 


\section{Discussion}

Germ cell tumors are divided into two major groups: germ cell and non-germ cell tumors (yolk sac tumor, choriocarcinoma, embryonal carcinomas, and teratomas). ${ }^{7}$ The latter group has a worse prognosis. ${ }^{6,7}$

In the presence of a tumor located in the midline, in a child or young adult, the hypothesis of a germ cell tumor should be considered. A search for tumor markers ( $\alpha$-fetoprotein and $\beta$-HCG) in the blood and/or in the cerebrospinal fluid (CSF) should be performed.

Germinomas are the most common tumors of this group; and, in this case, the markers are usually negative, and the diagnosis requires histological confirmation through biopsy. ${ }^{7}$ Since this type of tumor has an excellent response to radiotherapy, with long-term regression rates of $\sim 90 \%$, excision surgery does not lead to an improvement in the outcome. $^{7}$

On the other hand, the positivity of $\alpha$-fetoprotein labeling will determine the diagnosis of yolk sac tumor without the need of histological confirmation for therapeutic orientation. ${ }^{7}$ In the case described in the present report, this hypothesis was never raised due to the location of the lesion, which is why this study was not performed preoperatively.
The temporal location of a yolk sac tumor is extremely rare. To our knowledge, there are 19 cases reported in the literature $^{6,8}$ on the occurrence of this tumor outside the midline, with only 4 located in the cerebral lobes - the remaining reported cases occurred in the lateral ventricles, in the fourth ventricle, in the thalamus/basal ganglia, in the cerebellum, or in the rachis) ${ }^{6,8}$ (-Table $\mathbf{1}$ ).

The definitive diagnosis and correct orientation of a case like this requires an exhaustive study for the exclusion of an extracerebral primary tumor. In our case, this study included a thoracoabdominopelvic CAT scan, a testicular echography, and a PET scan, which were negative.

Germinomas are undifferentiated and aggressive tumors, with a poor response to the complementary treatment. Given the rarity of non-germ cell germ cell tumors histologies, in literature reviews of prognosis and survival these are often grouped in the same category, ${ }^{7}$ with a $45 \%$ survival rate at 2 years for this subgroup of tumors. From the 19 cases described outside the midline $e^{1,6}$ at the time of the respective publications, 4 patients had died in less than 1 year (in 4 cases, the survival was not described). Regarding the modalities of complementary treatment, 12 patients from the 19 cases were submitted to chemotherapy programs ( 5 in conjunction with radiotherapy). ${ }^{6,8}$ Two patients underwent the same scheme of the case presented here. Three patients

Table 1 Described cases of yolk sac tumors outside the midline

\begin{tabular}{|c|c|c|c|c|c|}
\hline Site & Author & Gender & Age (years) & Treatment & Survival (months) \\
\hline Spine & Kurisaka et al. & Female & 1 & Surgery + CT & $8^{\mathrm{b}}$ \\
\hline Spine & Kan et al. & Female & 25 & Surgery + RT + CT & $22^{b}$ \\
\hline Cerebellum & Takeda et al. & Male & 4 & Surgery + RT & $8^{a}$ \\
\hline Cerebellum & Tajika et al. & Male & 3 & Surgery $+\mathrm{CT}$ & $4^{a}$ \\
\hline Cerebellum & Tsukamoto et al. & Male & 3 & Surgery + RT + CT & $18^{\mathrm{a}}$ \\
\hline Cerebellum & Nakase et al. & Male & 5 & Surgery + CT & $12^{\mathrm{a}}$ \\
\hline Cerebellum & Wada et al. & Male & 6 & Surgery $+\mathrm{CT}$ & $5^{b}$ \\
\hline Cerebellum & Cheon et al. & Male & 3 & Surgery + CT & $48^{a}$ \\
\hline Basal ganglia & Masuzawa et al. & Male & 10 & Surgery + RT & $N A^{b}$ \\
\hline Basal ganglia & Oshita et al. & Female & 8 & Surgery + RT + CT & $N A^{b}$ \\
\hline Basal ganglia & Wang et al. & Female & 7 & Surgery + RT + CT & $\mathrm{NA}^{\mathrm{b}}$ \\
\hline Lateral ventricle & Murovic et al. & Female & 2 & Surgery + RT & $42^{a}$ \\
\hline Lateral ventricle & Tsugu et al. & Female & 13 & Surgery + RT + CT & $7^{b}$ \\
\hline Fourth ventricle & Nakagawa et al. & Male & 18 & Surgery + RT & $5^{a}$ \\
\hline Frontal lobe & Sugawara et al. & Female & 18 & Surgery + RT + CT & $3^{a}$ \\
\hline Frontal lobe & Netalkar et al. & Female & 15 & Surgery $+\mathrm{CT}$ & $36^{a}$ \\
\hline Frontal lobe & Honda et al. & Male & 1 & Surgery + CT & $9^{b}$ \\
\hline Middle fossa + orbit & Dragan et al. & NA & 15 & Surgery $+\mathrm{CT}$ & $5^{\mathrm{a}}$ \\
\hline Temporoparietal lobe & Abdennebi et al. & Female & 1 & Surgery + RT & $N A^{b}$ \\
\hline Temporal lobe & Present case & Male & 32 & Surgery $+C T+R T$ & $7^{b}$ \\
\hline
\end{tabular}

Abbreviations: CT, chemotherapy; NA, not available; RT, radiotherapy.

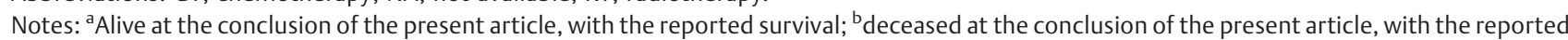
survival. 
received vinblastine + cisplatin + bleomycin. Two patients received carboplatin + etoposide + bleomycin. One patient received vincristine + cisplatin + bleomycin. One patient received etoposide + cisplatin + bleomycin. One patient received carboplatin + vinblastine + etoposide. One patient received intrathecal methotrexate and cytosine + carboplatin + bleomycin. And one patient received vinblastine +

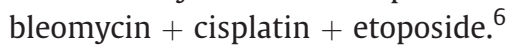

\section{Conclusion}

The tumor of the yolk sac of the CNS is a germ cell tumor with aggressive characteristics and poor prognosis. The present case reinforces the notion that, although rare, this tumor may occur outside the midline. Having no imaging characteristics that clearly distinguish it from other primary malignant CNS tumors, namely HGGs, it should be maintained as a diagnostic hypothesis in young individuals, since the therapeutic and prognostic orientation are markedly different for this type of tumor.

\section{References}

1 Tsugu H, Oshiro S, Ueno Y, et al. Primary yolk sac tumor within the lateral ventricle. Neurol Med Chir (Tokyo) 2009;49(11):528-531

2 Lazzareschi I, Furfaro IF, Coccia P, Puma N, Riccardi R. Extragonadal yolk sac tumor outside of the midline of the body: a case report of a child with a yolk sac tumor of the pontocerebellar angle. Tumori 2009;95(06):840-842

3 Verma R, Malone S, Canil C, Jansen G, Lesiuk H. Primary skullbased yolk-sac tumour: case report and review of central nervous system germ cell tumours. J Neurooncol 2011;101(01):129-134

4 Frank TC, Anand VK, Subramony C. Yolk sac tumor of the temporal bone: report of a case. Ear Nose Throat J 2000;79(03):183, 187-188, 191-192 passim

5 Utsuki S, Oka H, Tanizaki Y, Kondo K, Fujii K. Radiological features of germinoma arising from atypical locations. Neurol Med Chir (Tokyo) 2005;45(05):268-271

6 Wang $\mathrm{CH}$, Hsu TR, Yang TY, et al. Primary yolk sac tumor of bilateral basal ganglia. J Chin Med Assoc 2010;73(08):444-448

7 Odgen AT, Bruce JN. Pineal Region Tumors. In: Bernstein M. Neuro-oncology - The essentials. New York: Thieme Publishers; 2008:299-305

8 Schmidek H. Schmidek and Sweet Operative Neurosurgical Techniques. Philadelphia: Elsevier; 2000:908-915 